\title{
Keris Sebagai Jimat Dengan Pendekatan Ilmu Kalam
}

\author{
Ulfatun Hasanah \\ Jurusan Komunikasi Penyiaran Islam, Fakultas Dakwah dan Komunikasi \\ Universitas Islam Negeri Walisongo, 50185, Indonesia \\ ulfatunhasanah92@gmail.com
}

INFOARTIKEL

Riwayat Artikel:

DiterimaJuli 2018

Direvisi Agustus 2018

Disetujui September 2018
ABSTRAKSI

Abstrak:Keris sebagai alat untuk perlindungan dari ancamanancaman yang bersifat fisik maupun non fisik. Menurut Islam keris diperbolehkan sebagai alat perlindungan diri, yang tidak diperbolehkan Islam apabila keris disalahgunakan sebagai azimat (jimat). Hukum percaya keris sebagai azimat (jimat) dalam Islam adalah haram dan salah satu perbuatan musyrik (dosa besar). Pendekatan berarti cara pandang, paradigma, metodologi. Pendekatan ilmu kalam adalah cara pandang atau analisis terhadap masalah ketuhanan dengan menggunakan norma-norma agama atau simbol-simbol keagamaan yang ada. Signifikansi kajian ini adalah untuk menunjukkan keris sebagai jimat dengan pendekatan ilmu kalam.

\begin{abstract}
Keris is sort of Java traditional weapon for protection from threats that are both physical and non-physical. According to Islam, the keris is allowed only as a means of personal protection, which Islam is not permitted if the keris is misused as a talisman (amulet). Islam's law believes keris uses as a talisman (amulet) is haram and one of the idolatrous acts (big sin). The approach means perspective, paradigm, and methodology. The Kalam science's approach is a way of look or analyzing the problem of divinity by using religious norms or existing religious symbols. The significance of this study is to show how the keris as a talisman analyzed by Kalam science's approach
\end{abstract}

\section{Pendahuluan}

Masalah keyakinan (akidah) ataupun monoteisme murni (ilmu kalam) merupakan salah satu masalah yang fundamental dalam Islam yang menjadi pijakan umat Islam dalam kehidupan sehari-hari. Tanpa akidah yang mantap tidak mungkin (mustahil) seseorang bisa mengamalkan ajaran Islam secara sempurna. Oleh karena itu, dapatlah kita maklumi bahwa pada masa permulaan dakwah Rasulullah SAW di Makkah (periode Makkiyah), beliau lebih memprioritaskan penanaman akidah kepada umat Islam daripada ajaran yang lain. Barulah setelah keimanan mereka kokoh beliau meningkatkan kepada masalah syari'ah, muamalah, maupun doktrin yang lainnya.

Ilmu kalam adalah ilmu keislaman yang membahas masalah akidah atau keimanan berdasarkan argumen rasional dan, tentu saja, tanpa mengesampingkan nash al-Qur'an dan asSunnah. Di dalam pembahasannya, para mutakalim lazim mengetengahkan dalil rasional terlebih dahulu, lalu memperkuatnya dengan dalil nash al-Qur'an dan al-Hadits.

Ketika dunia Islam berada pada Dinasti Bani Abbas, pada Khalifah Al-Ma'mun (813-833), suasana perkembangan pemikiran umat mulai memperlihatkan kecenderungan baru. Pada penghujung abad pertama atau awal abad kedua hijriyah, muncul diskusi sistematis dan silang pendapat di sekitar persoalan kalam, seperti masalah iman dan kufur, pelaku dosa besar, dan 
masalah qadha dan qadhar. Diskusi ini pula yang pada gilirannya melahirkan ilmu kalam yang memusatkan materi bahasan pada aspek akidah Islamiah (ilmu kalam).

Dunia pusaka keris adalah dunia yang sangat menarik untuk dikaji. Mengapa demikian? Tidak bisa dipungkiri, banyak orang yang pro dan kontra terhadap benda peninggalan budaya yang satu ini. Ada banyak mitos yang berkembang di sekitarnya, ada pula yang menafikkannya dan menganggapnya suatu hal yang tidak penting. Salah satu mitos yang berkembang pada keris adalah keberadaannya yang digunakan sebagai jimat. "Percaya keris sebagai jimat" adalah salah satu bentuk syirik. Benda keramat, pusaka, benda antik, atau benda apa pun yang dianggap/dipercaya punya "kekuatan ghaib" dalam istilah bahasa Arab disebut "tamimah". Firman Allah SWT:

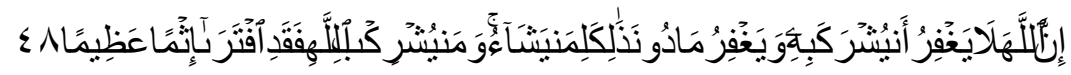

Artinya:"Sesungguhnya Allah tidak akan mengampuni dosa syirik dan Dia akan mengampuni dosa di bawah tingkatan syirik bagi siapa saja yang dikehendaki-Nya." (QS. An Nisaa' : 48). ${ }^{1}$

Dalam memahami agama banyak pendekatan yang dapat dilakukan. Hal demikian perlu dilakukan, karena pendekatan tersebut kehadiran agama secara fungsional dapat dirasakan oleh penganutnya, sebaliknya tanpa mengetahui berbagai pendekatan tersebut, tidak mustahil agama menjadi sulit difahami oleh masyarakat dan tidak fungsional. Berbagai pendekatan tersebut diantaranya ialah pendekatan ilmu kalam. Adapun yang dimaksud dengan pendekatan di sini adalah cara pandang atau paradigma yang terdapat dalam suatu bidang ilmu yang selanjutnya digunakan dalam memahami agama. Maka dari itu peneliti ingin mengupas lebih lanjut bagaimana "keris sebagai jimat" dengan pendekatan ilmu kalam.

\section{Kajian Pustaka}

\section{A. Pengertian Pendekatan Ilmu Kalam}

Kata pendekatan berasal dari bahasa Inggris approach yang berarti cara pandang atau paradigma terhadap sesuatu. Dalam Bahasa Arab disebut dengan madkhal. Dalam kamus Besar Bahasa Indonesia pendekatan yaitu: (1) proses pembuatan, cara mendekati; (2) usaha dalam rangka aktivitas penelitian untuk mengadakan hubungan dengan orang yang diteliti; metodemetode untuk mencapai pengertian tentang penelitian. Dalam konteks agama, pendekatan adalah cara pandang atau paradigma yang terdapat dalam suatu bidang ilmu yang selanjutnya digunakan dalam memahami agama. ${ }^{2}$

Secara bahasa (etimologi), kalam berasal dari bahasa Arab yang artinya pembicaraan, yakni pembicaraan yang bernalar dengan menggunakan logika atau nalar berfikir. Secara istilah (terminologi), ilmu kalam adalah salah satu cabang keilmuan Islam yang membahas tentang cara menetapkan kepercayaan atau keimanan terhadap agama menggunakan bukti-bukti yang telah menyakinkan. Ilmu kalam ini tidak jauh dari segi keimanan (rukun iman). Maka dari itu ada beberapa ahli menamai ilmu kalam dengan ilmu ushuluddin (ajaran dasar agama), ilmu aqo'id/akidah (keyakinan), ilmu tauhid (keesaan Allah SWT). Dalam perkembangan terakhir, termasuk di Indonesia ilmu ini mulai populer dengan nama teologi Islam (Ilmu tentang Ketuhanan $)^{3}$.

"Menurut Ibn Khaldun, ilmu kalam adalah keilmuan yang di dalamnya memuat argumen atau dalil yang bersifat rasional untuk digunakan sebagai pembelaan terhadap akidah yang diimani, dan memuat pengelakan terhadap golongan yang menyimpang dari madzab yang benar serta ahli sunnah.

\footnotetext{
${ }^{1}$ APP. 2007. Al-Qur'an dan Terjemahannya. Jakarta: PT. Indah Kiat Pulp \& Paper Tbk

${ }^{2}$ Ajahari. 2011. "Memahami Islam Perspektif Metodologis.” Jurnal Tarbiyatuna PAI, Vol. 1 (1), hal 4

${ }^{3}$ Khunaifi, Agus. 2012. Ilmu Tauhid (Sebuah Pengantar Menuju Muslim Moderan). Semarang: CV. Karya Abadi Jaya, hal 54
} 
Menurut Muhammad Abduh, ilmu kalam ialah ilmu yang membahas tentang wujud Allah, sifat-sifat wajib yang ada bagi-Nya, sifat-sifat jaiz yang sifatkan bagi-Nya, dan sifat-sifat yang tidak ada bagi-Nya. Ilmu kalam juga membahas tentang rasul-rasul Allah untuk menetapkan kebenaran risalahnya, apa yang wajib ada pada dirinya, hal-hal yang jaiz yang dihubungkan kepada diri mereka". Adapun skema ilmu kalam, sebagai berikut:

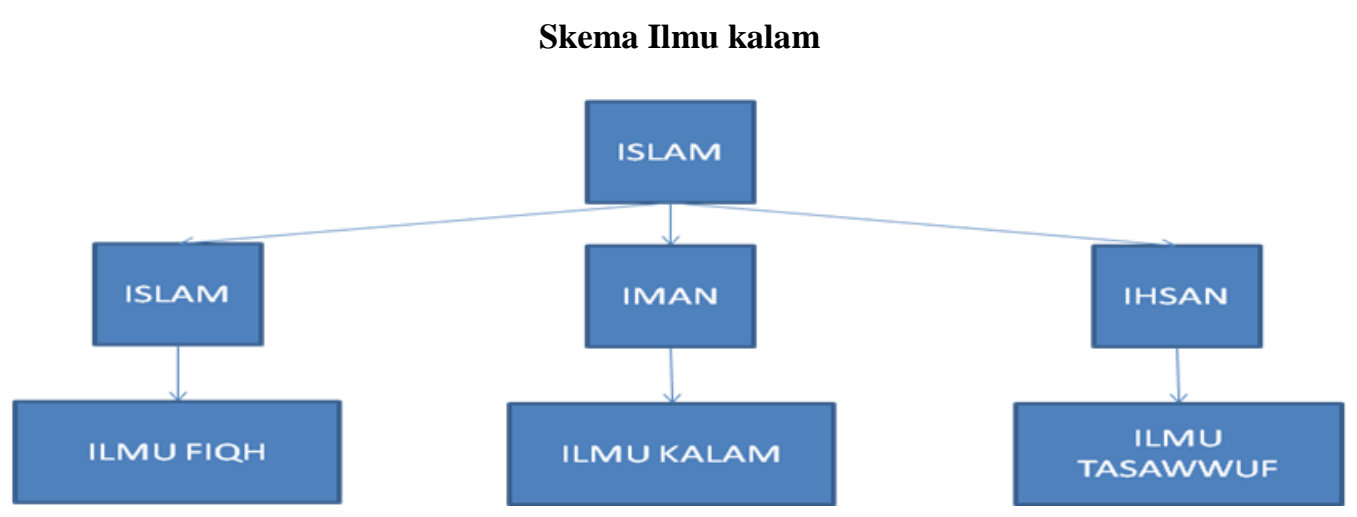

Fig. 1.Skema Ilmu kalam 5

Skema di atas bahwa yang menopang dan menguatkan sistem nilai ajaran Islam terdiri atas tiga pilar, yaitu: Iman sebagai landasan akidah. Islam sebagai manifestasi syariat, ibadah dan muamalah. Serta Ihsan sebagai aktualisasi akhlak. Menurut Hasan Al-Banna ruang lingkup ilmu kalam sendiri, meliputi illahiyyat (pembahasan ilmu kalam yang berkaitan tentang Allah SWT, baik wujud-Nya, sifat-Nya, maupun asma'-Nya), nubuwat (pembahasan terkait kenabian dan kerasulan, termasuk kitab dan mukjizatnya), Rohaniyyat (membahas hubungan sesuatu yang ghaib, mencakup malaikat, setan, jin, dan sejenisnya), dan Sam'iyyat (berkaitan dengan hal-hal yang hanya diterima melalui dalil-dalil atau pendengaran, misalnya alam kubur, akhirat, surga, dan sebagainya).

Berdasarkan uraian di atas, pendekatan ilmu kalam adalah cara pandang atau analisis terhadap masalah Ketuhanan dengan menggunakan norma-norma agama atau simbol-simbol keagamaan yang ada. Pendekatan ilmu kalam tidak bisa dilepas dari kehidupan umat beragama di tengahtengah masyarakat. ${ }^{6}$

\section{B. Sejarah Munculnya Ilmu Kalam}

Adapun sejarah munculnya ilmu kalam, sebagai berikut:

1. Masa Rasulullah SAW. Di zaman Nabi Muhammad SAW umat Islam dapat kompak dalam lapangan agama, termasuk di bidang akidah. Kalau ada hal-hal yang diperselisihkan di antara para sahabat, mereka mengembalikan persoalannya kepada Nabi. Maka penjelasan beliau itulah yang kemudian menjadi pegangan dan ditaati.

2. Masa Khulafaurrasyidin. Pada dasarnya masalah akidah di masa Khulafaurrasyidin tidak jauh berbeda dengan masa Rasulullah. Para Khalifah selalu menjaga akidah keimanan sebagaimana yang diajarkan oleh Rasulullah dan melaksanakan apa yang diperintahkan Allah serta menjauhi semua yang dilarangnya. Mereka juga berusaha tidak mempertentangkan masalah-masalah akidah. Dengan terbunuhnya Khalifah Utsman bin 'Affan, disusul dengan bai'at Ali bin Abu Thalib yang hanya disetujui oleh penduduk Madinah saja, diiringi dengan pertempuran-pertempuran di kalangan umat Islam yang

\footnotetext{
${ }^{4}$ Jamrah, Suryan A. 2015. Studi Ilmu Kalam. Jakarta: Kencana, hal 23

${ }^{5}$ Ibid, hal 24

${ }^{6}$ Mustafa, Muhdagin Dg. 2006. "Reorientasi Teologi Islam Dalam Konteks Pluralisme Beragama (Telaah Kritis dengan Pendekatan Teologis Normatif, Dialogis danKonvergensif)." Jurnal Hunafa, Vol. 3 (2)., hal 6

${ }^{7}$ Nasir, Salihun A. 2010. Pemikiran Kalam (Teologi Islam) Sejarah, Ajaran, dan Perkembangannya. Jakarta: Rajawali Pers., hal 57
} 
mengakibatkan timbul kekacauan politik, yang akhirnya menjurus pembentukan suatu aliran/paham di kemudian hari. Masalah Imamah dan syarat-syaratnya menjadi topik pembicaraan setelah terjadinya peristiwa khalifah Utsman terbunuh. Lebih lanjut dihubungkan dengan masalah siapa yang melakukan pembunuhan itu. Di sini timbul bibit paham Qadariyah dan Jabariyah.

3. Masa Bani Umayyah. Akibat dari kekacauan politik pada masa Khalifah Ustman bin 'Affan. dan Ali, timbul beberapa golongan dalam Islam, yaitu golongan Khawarij, Syi'ah dan Murji'ah. Golongan ini pada mulanya tumbuh disebabkan ada unsur politik, namun pada kelanjutannya berkembang menjadi aliran keagamaan. Hal ini terjadi disebabkan masing-masing berusaha untuk memperkuat pendirian-pendirian politik mereka dengan menggunakan dalih agama yang bisa menguntungkan politik mereka. Golongan Khawarij mengafirkan yang lain. Golongan Syi'ah mengkufurkan orang-orang berbuat dosa besar, dan mempercayai seorang imam termasuk rukun iman. Bagi golongan Murji'ah siapa beriman kepada Allah dan Rasul-Rasulnya sudah termasuk mukmin, meskipun dia berbuat dosa besar. Bahkan ada di kalangan Murji'ah yang berpendapat iman adalah kepercayaan dalam hati, meskipun lisannya mengatakan kekafiran. Kemudian timbul pendapat yang lain dan berpendapat bahwa orang yang melakukan dosa besar bukanlah kafir dan bukan pula mukmin. Pendapat ini dipelopori oleh Washil bin 'Atha yang kemudian menjadi aliran Muktazilah. Pada masa ini perbincangan masalah qadar dan masalah istith'ah yang dipelopori oleh Ma'bad al-Juhani Cs (Qadariyah). Di lain pihak ada yang meniadakan kudrat dan iradat manusia yang ditokohi oleh Jaham bin Safwan (Jabariyah).

4. Masa Bani Abbasiyah. Di masa ini masalah akidah Islam lebih kompleks persoalannya. Masalahnya lebih menjadi rumit apabila dibandingkan dengan masa Rasulullah dan Khulafaurrasyidin. Argumentasi-argumentasi yang digunakan untuk mengiktikadkan wujud Tuhan dan Keesaan-Nya sangat berbeda dengan jaman-jaman sebelumnya. Demikian pula masalah zat dan sifat serta qadha dan qadar di jaman Rasulullah dan Khalifaturrasyidin tidak diperbincangkan, akan tetapi pada masa ini masalah tersebut benar-benar menjadi obyek persoalan. Di samping masalah itu juga masalah "sifat aktif", "sifat ilmu", "sifat kalam", kejasmanian", "arham", "ru’yah", dan keadilan Tuhan menjadi objek pembicaraan di antara mutakallimin. Tokoh-tokoh mutakallimin yang dikenal di masa ini antara lain Washil bin Atha (pendiri aliran Muktazilah), Imam Asy'ari (pendiri aliran Asy'ariyah), dan Maturidy (pendiri aliran Maturidiyah).

Lahirnya ilmu kalam yang berkembang di masa Abbasyiah dan sekarang menjadi panutan umat Islam di jaman ini, seperti di Indonesia. ${ }^{8}$

\section{Pijakan Paradigmatik-Teoritis Ilmu Kalam}

Sebuah disiplin ilmu lahir dari sebuah proses revolusi paradigma/pendekatan. Paradigma itu sendiri sering disebut dengan cara pandang atau world view atau teori dominan dari ilmu tertentu.

Pada konteks pendekatan ilmu kalam, paradigma yang digunakan adalah paradigma burhani, yakni the nature of knowledge (realisme, realitas sosial, dan realitas alam), the origin of knowledge (realitas tersebut dikaji secara rasional empiris, metode ilmiah), dan the validity of knowledge (objektif dan intersubjektif). ${ }^{9}$

Adapun pijakan paradigmatik-teoritis Ilmu kalam/teologis dalam memahami agama sendiri ada tiga macam, sebagai berikut:

1. Paradigma Teologis Normatif. Paradigma teologis normatif dalam memahami agama, ialah upaya memahami agama dengan menggunakan kerangka ilmu Ketuhanan 
yang bertolak dari suatu keyakinan bahwa wujud empirik dari suatu keagamaan dianggap sebagai yang paling benar bila dibandingkan dengan yang lainnya. Melihat agama sebagai suatu kebenaran yang mutlak dari Tuhan, tidak ada kekurangan sedikit pun dan nampak bersifat ideal. ${ }^{10}$

2. Paradigma Teologis-Dialogis. Dalam Kamus besar bahasa Indonesia, dialogis berasal dari kata dialog, yang berarti percakapan, cerita. Sedangkan dalam Kamus Inggris-Indonesia, kata dialogis atau dialogue berarti perbincangan atau percakapan. Dari beberapa pengertian dialogis ini maka dapat dipahami bahwa yang dimaksud dengan paradigma dialogis dalam pembahasan ini adalah metode pendekatan terhadap agama melalui dialog nilai-nilai normatif masing-masing aliran atau agama. Oleh karena itu, perlu adanya keterbukaan antara satu agama dengan agama lainnya.

3. Paradigma Teologis-Konvergensi. Kata "konvergensi" berasal dari kata "converge" yang berarti bertemu, berkumpul atau berjumpa. Selanjutnya kata ini menjadi "convergence" yang berarti tindakan bertemu, bersatu di satu tempat, pemusatan pandangan mata ke suatu tempat yang amat dekat, atau menuju ke suatu titik pertemuan atau memusat. Maksudnya dari pendekatan ini ialah ingin mempersatukan unsur-unsur esensial dalam agama-agama, sehingga tidak nampak perbedaan yang esensial. Dalam kondisi demikian, agama dan penganutnya dapat disatukan dalam satu konsep teologi universal dan umatnya disatukan sebagai satu umat beragama

Dari ketiga metode paradigma teologis tersebut di atas, maka yang paling akurat dipergunakan menurut analisa penulis adalah pendekatan teologis konvergensi, di mana pendekatan ini telah tercakup di dalamnya nilai-nilai normatif dan dialogis. Lain halnya hanya dengan menggunakan metode pendekatan normatif atau dialogis saja, belum tentu terdapat unsur konvergensi di dalamnya. ${ }^{11}$

\section{Langkah Praktis-Metodis Pendekatan Ilmu Kalam}

Dalam pendekatan ilmu kalam terdapat langkah-langkah praktis-metodis, sebagai berikut (1) Menentukan topik atau tema yang akan diteliti; (2) Pengumpulan data dengan cara: observasi/pengamatan, interview/wawancara, dan dokumentasi; (3) Menentukan dialektika dengan konteks yang diteliti; (4) Interpretasi (analisis) dan mendiskripsikan topik tersebut agar berkembang di dalam masyarakat; (5) Laporan hasil penelitian. ${ }^{12}$

\section{E. Tokoh Pendekatan Ilmu Kalam}

Banyak tokoh dalam pendekatan ilmu kalam yang penulis tidak dapat sebutkan semuanya, adapun tokoh pendekatan ilmu kalam era modern antara lain:

1. Imam Al-Farugi. Dengan pemikirannya menjelaskan tentang tauhid adalah tauhid sebagai inti agama pengalaman, pandangan dunia, intisari Islam, prinsip sejarah, prinsip pengetahuan, prinsip metafisik, etika, tata sosial, umamah, keluarga, tata politik, ekonomi dan estetika. Contoh karyanya "Tauhid: Its Implications for Thought and life (1982).

2. Imam Ahmad Hanafi. Dokrin Imam ahmad Hanafi tentang: teologi tradisional; teologi tradisional menurutnya lahir dalam konteks sejarah kepercayaan keda Tuhan diserang oleh sikte budaya lama dengan tujuan menahan dokrin lama, tetapi zaman sekarang sudah berubah. Kemudian beliau menawarkan konsep perlunya rekontruksi teologi. Contoh karyanya Qadhanya Mu'ashirat fi Fikrina Al-Mu'ashir (1976), Al-Turats wa Al-Tajdid, dan sebagainya.

\footnotetext{
${ }^{10}$ Nalion, Amfa, Pendekatan Teologi Ilmu Kalam, dalam http : // amvanalion. blogspot. co. Id / p /pendekatan-teologiilmu-kalam.html, pada 5 Maret 2015, hal 5

${ }^{11}$ Mustafa, Muhdagin Dg. 2006. "Reorientasi Teologi Islam Dalam Konteks Pluralisme Beragama (Telaah Kritis dengan Pendekatan Teologis Normatif, Dialogis danKonvergensif).” Jurnal Hunafa, Vol. 3 (2), hal 6

${ }^{12}$ ibid, hal 7
} 
3. Harun Nasution. Pemikiran beliau dengan ilmu kalam adalah pertama, tentang peran akal dalam Islam memberikan pengaruh besar. Kedua, perlunya pembaharuan teologi, maksud pembaharuan tersebut adalah teologi Islam harus mengacu pada konsep free-will, rasional, dan mandiri. Ketiga, perlunya hubungan antara wahyu dengan akal. Banyak buku yang sudah ditulisnya, seperti: Islam ditinjau dari berbagai aspeknya, teologi Islam, dan sebagainya. ${ }^{13}$

\section{F. Keris sebagai Jimat dengan Pendekatan Ilmu Kalam}

Hukum menyakini atau mempercayai benda pusaka didasarkan pada keyakinan kita dalam menilai benda tersebut. Sedangkan bagi banyak orang yang meyakini adanya mahkluk gaib di dalam benda-benda pusaka itu, kemudian meminta bantuan makhluk gaib yang ada di dalamnya apalagi dengan melakukan ritual seperti pembakaran dupa dan pembacaan ajian-ajian atau mantra, maka bisa berakibat kekufuran jika meyakini dengan ritual tersebut jin yang ada di dalamnya bisa tunduk dan mau melakukan segala kehendaknya. Padahal semua kekuatan dan sumber kekuatan hanyalah dari Allah SWT semata. ${ }^{14}$

Jimat atau tamimah pada masa jahiliyah adalah sesuatu yang dikalungkan pada anak kecil atau binatang dengan maksud untuk menolak 'ain. Namun hakikat jimat tidak terbatas pada bentuk dan kasus tertentu akan tetapi mencakup semua benda dari bahan apapun dan bagaimanapun cara pakainya. Adapun bentuk-bentuk jimat yang ada di masyarakat, antara lain: (1) batu akik, keris, rajah, rantai babi, mustika, benda-benda bertuah, dan lain-lain, (2) jimat keberuntungan, (3) jimat penghasilan, (4) jimat penglaris dagangan, (5) jimat kekuatan dan keberanian, (6) jimat kebal senjata tajam, (7) jimat perlindungan diri, (8) jimat perlindungan kendaraan dan rumah, (9) jimat kecintaan, (10) jimat keselamatan, dan sebagainya.

Keris berasal dari bahasa sansekerta yaitu kres yang berarti menghunus, kemudian di dalam bahasa Jawa kuno menjadi kris, dan akhirnya masyarakat Jawa saat ini mengenalnya dengan sebutan keris. Ejaan keris banyak ditemukan dalam literatur Barat, di antaranya: karis, calis, crist, cries, crest, kriss dan krees. Salah satu peneliti yang menciptakan keris adalah Wanapalawijaya (230 M). Keris juga didapati di berbagai negara tetangga, terutama di bekas wilayah kekuasaan Kerajaan Majapahit dan Sriwijaya. ${ }^{15}$

Percaya keris sebagai azimat (jimat) dengan pendekatan ilmu kalam termasuk salah satu perbuatan syirik (musyrik). Syirik adalah lawan dari tauhid, yang berarti mempercayai banyak Tuhan selain Allah, yang dalam istilah Barat disebut politeisme. Pelaku tindakan syirik disebut musyrik. Dengan demikian, syirik adalah penyimpangan dari akidah tauhid yang diajarkan oleh para Nabi dan Rasul Allah.

Para ulama lazim membedakan syirik ini kepada syirik nyata (syirik besar) dan syirik terselubung (syirik kecil). Syirik nyata adalah tindakan kemusyrikan yang mempercayai atau menyekutukan Allah dengan Tuhan atau beberapa Tuhan yang lain. Syirik terselubung adalah tidak menyentuh langsung masalah bilangan Tuhan, melainkan lebih banyak berkaitan dengan perilaku keberagaman yang menyentuh aspek tauhid sifat dan af'al, seperti sifat sombong dan pamer.

Umat Islam dapat dijamin tidak akan terjerumus kepada syirik nyata, dalam arti secara sadar mengakui adanya Tuhan selain Allah. Namun tidak demikian halnya dengan syirik terselubung, kemungkinan umat Islam melakukannya sangat besar. Karena syirik ini sangat halus dan terselubung.

\footnotetext{
${ }^{13}$ Mustafa, Muhdagin Dg. 2006. "Reorientasi Teologi Islam Dalam Konteks Pluralisme Beragama (Telaah Kritis dengan Pendekatan Teologis Normatif, Dialogis danKonvergensif).” Jurnal Hunafa, Vol. 3 (2), hal 7

${ }^{14}$ Kusein, Rajin Salat Tetapi Percaya Azimat, dalam http: // inilahrisalahislam. blogspot. co. Id / 2016/ 02/rajin-sholat-tapi-percayaazimat.html, pada 10 Februari 2016, hal 7

${ }^{15}$ Mustafa, hal 37
} 
Begitu tersembunyinya syirik terselubung ini, sehingga sangat sulit dideteksi. Oleh karenanya, umat Islam harus waspada dan hati-hati. Sejauh tidak melakukan syirik nyata, seorang muslim mungkin masih dapat dikatakan sebagai ahli tauhid, tetapi dengan melakukan syirik terselubung ini berarti telah menodai kemurnian akidah tauhid itu sendiri. Tidak mustahil, bila syirik terselubung ini dilakukan terus-menerus, lebih-lebih dalam kondisi mengetahui dan sadar, dapat mendekatkan bahkan menjerumuskan seseorang pada syirik nyata. Misalnya, percaya keris sebagai jimat dapat mendatangkan keberuntungan, kekayaan, pelet, dan sebagainya, berarti ia telah menodai bahkan merusak kemurnian tauhid uluhiyyah. Karena, tindakan ini jelas telah menyimpang dari prinsip tauhid yang percaya adanya "kekuatan ghaib" di dalam keris. ${ }^{16}$ Apabila sampai keris digunakan sebagai azimat (jimat) Allah berfirman :

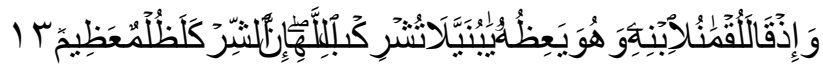

Artinya:"Dan (ingatlah) ketika Luqman berkata kepada anaknya, di waktu ia memberi pelajaran kepadanya: "Hai anakku, janganlah kamu mempersekutukan Allah, sesungguhnya mempersekutukan (Allah) adalah benar-benar kezaliman yang besar.” (QS. Lukman: 13) ${ }^{17}$

Dan firmannya pula:

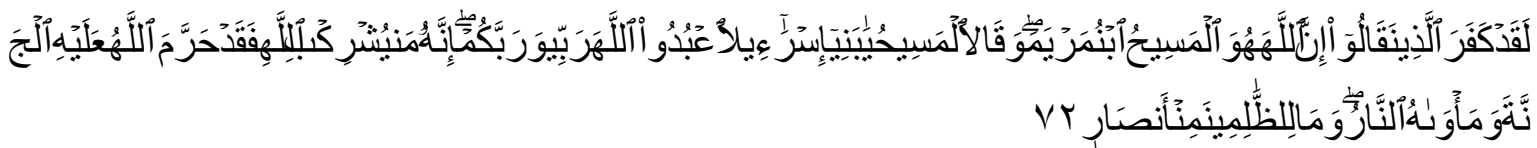

Artinya:"Sesungguhnya telah kafirlah orang-orang yang berkata: "Sesungguhnya Allah ialah Al Masih putera Maryam", padahal Al Masih (sendiri) berkata: "Hai Bani Israil, sembahlah Allah Tuhanku dan Tuhanmu". Sesungguhnya orang yang mempersekutukan (sesuatu dengan) Allah, maka pasti Allah mengharamkan kepadanya surga, dan tempatnya ialah neraka, tidaklah ada bagi orangorang zalim itu seorang penolongpun.” (QS. Al-Maidah: 72) ${ }^{18}$

Dalam hadits yang shahih disebutkan bahwa Rasulullah SAW bersabda: "Maukah kutunjukkan padamu dosa yang paling besar?" Hal itu dinyatakan oleh Nabi SAW sebanyak tiga kali. Lalu para sahabat menjawab: "Ya, tunjukkanlah, wahai Rasulullah." Nabi lalu menjawab: "Yaitu menyekutukan Allah (dengan sekutu), dan durhaka kepada kedua orang tuanya (Ibu dan Bapaknya)." Nabi dalam keadaan bertongkat lalu duduk sambil mengatakan "Ketahuilah pula, dosa beromong yang dusta dan bersaksi palsu." Sahabat berkata: "Senantiasa Nabi mengulangi ucapan tersebut sampai kami mengharapkan semoga Nabi itu diam." (HR. Bukhari dan Ahmad). ${ }^{19}$

Islam mengharuskan umatnya percaya pada hal ghaib, namun yang dimaksud ghaib yang harus diimani itu adalah Allah SWT, para malaikat, dan hari akhir. Penyebab syirik antara lain: taklid/meniru, keterbatasan daya pikir, kekosongan, hawa nafsu, dan faktor lain (sombong) (Kusein, 2016: 3). (1) Selain percaya keris sebagai jimat merupakan perbuatan syirik masih banyak tidakan lain yang berupa mitos dan khurafat seperti telah diuraikan dapat menodai dan merusak kemurnian akidah tauhid yang pelakunya tertangkap ke dalam syirik terselubung, antara lain; (2) Seseorang yang pergi berziarah ke makam orang tertentu misalnya, lalu meminta sesuatu kepada orang yang telah menjadi tulang belulang di liang lahat tersebut, berarti ia telah menodai bahkan merusak kemurnian tauhid. (3) Seseorang yang menyajikan sesajen dengan maksud menjalin hubungan dengan roh halus yang diyakini sebagai penjaga tempat tertentu, berarti telah menodai bahkan merusak tauhid. (4) Riya' (pamer agar dipuji dan dipandang hebat) dan sombong merupakan salah satu syirik terselubung. (5) Memakai gelang, benang, dan sejenisnya sebagai

\footnotetext{
${ }^{16}$ Jamrah, Suryan A. 2015. Studi Ilmu Kalam. Jakarta: Kencana. Hal 61-63

${ }^{17}$ APP. 2007. Al-Qur'an dan Terjemahannya. Jakarta: PT. Indah Kiat Pulp \& Paper Tbk

${ }^{18}$ Ibid

${ }^{19}$ Muhammad, Imam Abu Abdullah. 1990. Dosa-Dosa Besar. Surabaya: Bina Ilmu Offset., hal 5-6
} 
pengusir dan penangkal mara bahaya termasuk perbuatan syirik. Imran bin Husain menuturkan bahwa Rasulullah melihat seorang yang memakai halqah dari kuningan.

Beliau lantas bersabda: “Apa ini?" Orang itu menjawab, "Penangkal sakit." Nabi bersabda, "Lepaskanlah barang itu. Barang itu hanya akan menambah kelemahan pada dirimu. Kalau engkau meninggal padahal halqah itu masih engkau pakai maka engkau tidak akan beruntung selama-lamanya." (Hasan, diriwayatkan oleh Ahmad dan Ibnu Majah). ${ }^{20}$

\section{G. Keris dilihat dalam Perspektif Islam}

Keris disebut juga tosan aji. Tosan berasal dari kata tos atau atos yang berarti keras (besi), sedangkanaji berarti berharga bernilai atau luhur, jadi tosan ajiberarti besi yang bernilai.Keris adalah salah satu senjata tikam yang terbuat dari campuran bahan besi, baja, dan pamor (nikel, batu meteor, besi pamor). Al-Qur'an menjelaskan bahwa Allah telah menurunkan besi agar dapat dimanfaatkanmanusia, yaitu dalam surat Al-Hadid ayat 25:

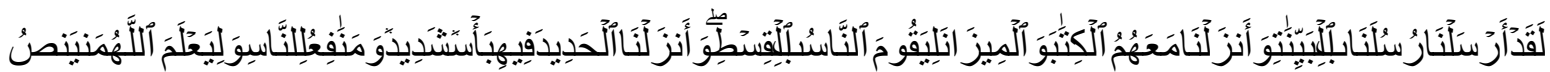

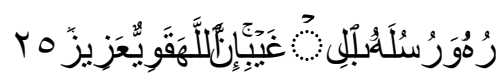

Artinya:“Sesungguhnya Kami telah mengutus rasul-rasul Kami dengan membawa bukti-bukti yang nyata dan telah Kami turunkan bersama mereka Al Kitab dan neraca (keadilan) supaya manusia dapat melaksanakan keadilan. Dan Kami ciptakan besi yang padanya terdapat kekuatan yang hebat dan berbagai manfaat bagi manusia, (supaya mereka mempergunakan besi itu) dan supaya Allah mengetahui siapa yang menolong (agama)Nya dan rasul-rasul-Nya padahal Allah tidak dilihatnya. Sesungguhnya Allah Maha Kuat lagi Maha Perkasa.” (QS. Al-Hadid: 25) ${ }^{21}$

Islam tidak pernah melarang manusia memiliki sebilah keris, karena fungsikeris selain sebagai alat penusuk juga sebagai alat untuk mempertahankan diri dariancaman-ancaman. Allah memerintahkan umat-Nya untuk membuat alat yangdapat melindungi dirinya dari peperangan, yaitu dalam surat Saba' ayat 11:

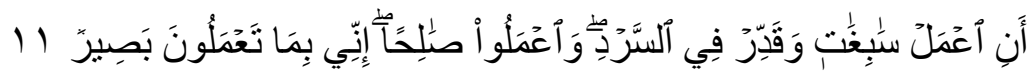

Artinya:"(yaitu) buatlah baju besi yang besar-besar dan ukurlah anyamannya; dan kerjakanlah amalan yang saleh. Sesungguhnya Aku melihat apa yang kamu kerjakan.” (QS. Saba': 11) ${ }^{22}$

Zaman sekarang ini, dapat dilihat bahwa banyak peralatan yang dibuatmanusia tidak lepas dari bahan besi, salah satunya adalah keris. Keris diciptakan manusia dengan berbagai macam kegunaan. Keris adalah senjata yang digunakanuntuk mempertahankan diri dari serangan lawan.Teknologi pembuatan keris saat ini menggunakan bara api yang panas.

Awalnya besi dibakar di dalam pembakaran hingga besi berwarna merah (sepertiapi), kemudian besi ditempa di atas paron besi atau landasan besi bekali- kali.Proses pengolahan besi seperti ini, juga di jelaskan dalam Al-Qur'an surat Al-Kahfi ayat 96:

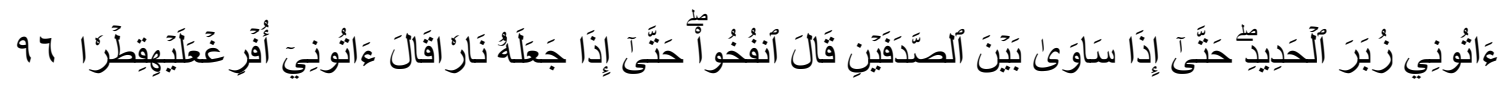

Artinya:Berilah aku potongan-potongan besi. Hingga apabila besi itu telah sama rata dengan kedua (puncak) gunung itu, berkatalah Dzulkarnain: "Tiuplah (api itu)". Hingga apabila besi itu sudah

\footnotetext{
${ }^{20}$ Jamrah, Suryan A. 2015. Studi Ilmu Kalam. Jakarta: Kencana. Hal 63-65

${ }^{21}$ APP. 2007. Al-Qur'an dan Terjemahannya. Jakarta: PT. Indah Kiat Pulp \& Paper Tbk

${ }^{22}$ ibid
} 
menjadi (merah seperti) api, diapun berkata: "Berilah aku tembaga (yang mendidih) agar aku kutuangkan ke atas besi panas itu." (QS. Al-Kahfi: 96) ${ }^{23}$

Jenis bahan besi yang digunakan untuk membuat keris ada bermacam-macam jenis. Namanama besi bahan keris antara lain: Besi karang kijang, besipuroseni, besi mangangkang, besi walulin, besi katum, besi kamboja, besi ambal, besi sinduaji, besi tumpang, besi warani, besi welangi, besi terate, besi malelalui yung, besi malela, besi kenur, besi tumbuk, besi balitung, besi keleman, besi penuh, dan masih banyak lagi jenisnya.

Bahan-bahan tersebut digunakansesuai $\begin{gathered}\text { keinginan } \\ \text { pembuat }\end{gathered}$ keris.
Agama Islam tidak pernah melarang manusia untuk memiliki keris,
apabila ada pandangan yang mengatakan bahwa keris adalah benda yang akan
menyesatkan kepercayaan manusia terhadap Tuhan (musyrik) maka yang patut
disalahkan adalah orang yang memiliki keris bukan keris itu sendiri.Manusia
diciptakan Tuhan sebagai makhluk yang paling tinggi martabatnya dibandingkan
dengan makhluk ciptaan Tuhan lainnya. Manusia diciptakan Tuhan dilengkapi
dengan akal dan pikiran, sedangkan keris hanyalah benda mati ciptaan manusia.
Keris sebagai saksi sejarah kemerdekaan, banyak tokoh pejuang zaman
dahulu, berjuang melawan penjajah Belanda dengan sebilah keris, di antaranya:
Pangeran Diponegoro, Tuanku Imam Bonjol, Panglima Sudirman, Kiai Maja, dantokoh pejuang
lainnya. Tokoh-tokoh tersebut tidak mungkin dikatakan musyrikkarena mereka merupakan orang
yang gigih dalam berjuang di jalan Allah,mereka taat menjalankan perintah agama dan mereka
termasuk orang yang sukamelakukan prihatin.

Anggapan-anggapan yang mengatakan bahwa keris adalah benda yang dapat menyesatkan manusia, mungkin didasari pada fenomena-fenomena yang ada di masyarakat saat ini. Orang-orang sering memberikan penghormatan yang berlebihan pada sebilah keris, bahkan ada yang menyembah terlebih dahulu sebelum membuka keris dari warangkanya.Perilaku-perilaku semacam itu, bagi komunitas pecinta keris tidaklah disalahkan, asal sewajarnya saja dan tidak berlebihan. Al-Qur'anmenjelaskan bahwa Allah tidak menyukai sesuatu yang berlebihan, yaitu:

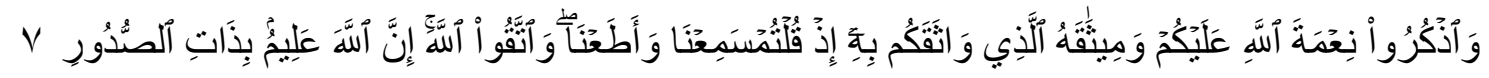

Artinya:"Dan ingatlah karunia Allah kepadamu dan perjanjian-Nya yang telah diikat-Nya dengan kamu, ketika kamu mengatakan: "Kami dengar dan kami taati". Dan bertakwalah kepada Allah, sesungguhnya Allah Mengetahui isi hati(mu)". (QS. Al-Maidah: 7) ${ }^{24}$

Menghormati keris, dalam dunia perkerisan diperbolehkan, asal tidak berlebihan. ${ }^{25}$ dalam bukunya yang berjudul "Tanya jawabsoal keris" memberikan gambaran bagaimana menghormati benda secara wajardan tidak berlebihan:

"Secarik kain berwarna merah terkadang digunakan sebagai lap debu. Kain putih sering dipakai untuk bahan sarung bantal. Apabila kedua carik kain tersebut dijahit dan disambung menjadi sebuah bendera, maka kita akan menempatkan Sang Dwi Warna itu di tempat yang terhormat, bahkanpada upacara-upacara resmi, kita akan memberikan penghormatan kepadabendera itu. Penghormatan yang kita lakukan,

\footnotetext{
${ }^{23}$ APP. 2007. Al-Qur'an dan Terjemahannya. Jakarta: PT. Indah Kiat Pulp \& Paper Tbk

${ }^{24} \mathrm{Ibid}$

${ }^{25}$ Harsrinuksmo, Bambang. 1985. Tanya Jawab Soal Keris. Jakarta: PT. Grafikatama Jaya., hal 19
} 
tentu bukan karena duacarik kain yang berwarna merah dan putih, melainkan lambang yang tersirat pada bendera itu. Merah Putih adalah lambang kedaulatan tanah air kita."

Cara menghormati keris yang benar dan wajar adalah dengan tidak menempatkan keris di sembarang tempat, tidak menaruhnya di dapur, gudang, bagasi mobil dan sebagainya. Cara memegangnya juga tidak seperti memegang golok pencacah daging atau pisau dapur.

Perilaku semacam itu (penghormatan keris yang berlebihan) dapat memberikan citra yang kurang baik terhadap keris. Masyarakat menganggap kerissebagai benda yang menakutkan, karena dapat menyesatkan manusia terhadap Tuhan. Perilaku itu dilakukan karena ketidak pahaman manusia terhadap ilmutentang perkerisan. Zaman dahulu, keris digolongkan sebagai "ngelmu ingkangsinengker" ilmu yang tidak boleh diajarkan kepada sembarang orang, bahkananaknya sendiri.

Mencuci atau merawat keris diperbolehkan, karena keris merupakan sebuah benda yang terbuat dari logam, dan mudah terkena karat. Merawat keris dapat dilakukan dengan cara memberikan minyak. Umumnya, orang yang memberikan minyak pada keris memiliki tujuan untuk memberi makan atau merawat keris dari karatan. Orang beranggapan bahwa merawat keris termasuk perbuatan musyrik, tetapi pada kenyataannya tidak, tergantung dari mana orang yang memandangnya.

Jadi, keris jika dilihat dari perspektif Islam dan dari uraian di atas maka keris tidaklah bertentangan dengan ajaran Islam, mana kala hanya dijadikan sebagai aksesori. ${ }^{26}$ Namun, apabila sampai keris digunakan sebagai azimat (jimat) hukumnya haram/dosa besar dalam Islam. ${ }^{27}$

\section{H. Studi Kasus Pendekatan Ilmu Kalam}

"Fungsi dalam mempelajari ilmu kalam adalah untuk menjadi dasar atau fondasi bagi keimanan kaum muslimin agar tidak mudah goyah dengan adanya goncangan akidah, serta tidak mudah untuk tersesat dengan akulturasi budaya yang seringkali mengaburkan ajaran Islam."28

Berikut ini contoh studi kasus dengan pendekatan Ilmu Kalam diambil dari kisah nyata Yogi yang mana perbuatannya menimbulkan kemusyrikansebagai berikut: ${ }^{29}$

Kisah Misteri: Persugihan Keris Omyang Jimber

(Oleh: Yogi)

Namaku Yogi, sebut saja begitu, umurku 52 tahun. Aku tinggal di sebuah perumahan di Jakarta Selatan bersama isteri dan dua orang putraku. Sampai penghujung tahun 2007, rumah tanggaku tidak menemui masalah yang berarti.Kami hidup rukun dengan segala kebutuhan rumah tanggayang selalu bisa aku penuhi. Dua orang putraku pun bisa bersekolah dengan layak, salah satunya sudah duduk dibangku perguruan tinggi dan adiknya masih di bangku SMP.

Tapi suatu ketika musibah datang beruntun dan langsung membuatku ambruk hingga tenggelam ke dalam lumpur kenistaan. Padahal baru saja dua bulan aku mengambil kredit di sebuah bank swasta Nasional yang nialinya 700 juta rupiah. Untuk mendapatkan kredit sebesar itu, aku mengagunkan rumah yang aku tempati bersama isteri dan anak-anakku. Uang sejumlah itu aku gunakan untuk modal usaha karena aku sudah lama mendapatkan klien dari Singapura mengirim hiasan rumah tradisional.

Seperti disambar petir di siang bolong, hari itu aku mendapat kabar bahwa barang yang kupesan

\footnotetext{
${ }^{26}$ Munir, Muhammad Khafidlil. 2015. “Memahami Konsep Keris Menurut Mt Arifin Dalam Tinjauan Islam.” Skripsi S1, hal 105

${ }^{27}$ Fakih, Abdul Latif. 2011. Tauhid (Sebuah Akidah Pembebasan). Pamulang: Inbox, hal45

${ }^{28}$ Mustafa, Muhdagin Dg. 2006. “Reorientasi Teologi Islam Dalam Konteks Pluralisme Beragama (Telaah Kritis denganPendekatan Teologis Normatif, Dialogis danKonvergensif)." Jurnal Hunafa, Vol. 3 (2), hal 3

${ }^{29}$ Bilikmisteri, Kisah Misteri: Ritual Persugihan Omyang Jimbe, dalam http://www. Bilikmisteri.web.id/, pada 16 November $2016 .$, hal 1
} 


\begin{abstract}
dari para pengrajin di Tasikmalaya tidak bisa dikirimkan. Alasan mereka belum mendapatkan bayaran sejak tiga bulan yang lalu.Para pengrajin itu menuntut pembayaran semua barang yang mereka kirim senilai hampir setengah milyar. Padahal aku sudah membayarkan semua hak mereka tanpa ada yang aku tunda-tunda. Pembayaran itu aku lakukan melalui kasir dan orang kepercayaanku.
\end{abstract}

Tak hanya itu, masalah lain timbul dari klienku yang di Singapura, dia menuntut aku untuk segera mengirimkan barang pesanannya. Panik bukan kepalang, di satu sisi aku harus membayar uang kepada para pengrajin di Tasikmalaya. Di sisi lain aku dituntut untuk mengirim barang di Singapura atau kontrak yang telah kubangun akan segera diputuskan. Artinya aku akan kehilangan klien sekaligus harus membayar utang yang segunung jumlahnya.

Yah, tentu saja bukan aku tidak mencari jalan keluar. Aku sudah melaporkan penggelapan uang, penipuan, dan korupsi pada Kepolisian. Tapi apa pun itu, tidak membuat usahaku lancar. Aku kehilangan klien karena ulah karyawanku yang membawa kabur uangku. Aku tak tahu ke mana harus mencarinya lagi. Alamat yang ditinggalkannyaketika melamar pekerjaan 4 tahun ternyata palsu. Aku sudah menelusuri semua jejak yang pernah dia tinggalkan, tapi semua nihil.

Singkat cerita, aku benar-benar terpuruk, usahaku hancur dan rumahku disita bank karena aku tak mampu membayar hutang. Aku ngontrak di sebuah rumah petakan di Cinere. Tapi itu belum bisa membuat hidupku tenang. Karena perajin di Tasikmalaya masih terus memburuku karena aku masih mempunyai hutang hampir sejumlah 400 juta rupiah. Nyaris setiap hari aku didatangi orang yang menagih hutang dan hampir setiap jam telepon genggamku berbunyi oleh orang-orang yang menagih hutang.

Keterpurukanku itu berlangsung hingga tahun 2009. Sepanjang dua tahun, hidupku benar-benar hancur, untuk mencari makan saja harus meminta bantuan kemana-mana. Anak sulungku terpaksa harus berhentikuliah dan isteriku setiap hari harus ikut mencari nafkah dengan berjualan gorengan dan makanan kecil di depan kontrakan.

Hari itu temanku Haris memperkenalkan aku pada seorang temannya yang bernama Edi. Menurut Haris, temannya yang bernama Edi itu bisa membantu menyelesaikan masalahku dengan

kekuatan ghaib. Tertarik dengan hal itu, aku mengajak Haris bertemu dengan Edi di suatu tempat di bilangan Bekasi.Dan hari itu pula aku diajak Edi bertemu dengan seorang spiritualis yang bernama Wisnu. Dari Mas Wisnu inilah aku diberitahu bahwa aku bisa menggelar ritual untuk mendapatkan sejumlah uang dari ghaib.

Menurut Wisnu, spiritualis yang berusia 45 tahun itu, ritual menarik uang ghaib ini menggunakan kekuatan keris Omyang Jimbe. Sebuah keris keramat yang umurnya sudah ratusan tahun.Di rumah mas Wisnu, aku diperlihatkan sebuah keris yang di kepalanya berhias dua orang yang nampak sedang semedi. Itulah yang disebut Mpu Omyang Jimbe pembuat keris pusaka yang kekuatan ghaibnya bisa digunakan untuk menarik uang dari alam ghaib.

Aku semakin antusias karena menurut mas Wisnu tak perlu tumbal untuk mendapatkan uang dari alam ghaib itu. Ghaib tersebut hanya menuntut ritual itu berlaku jujur. Sebab uang yang bisa ditarik dari alam ghaib itu hanya boleh dipergunakan untuk membayar hutang. Yah, dengan bermodalkan keyakinan aku menghadap Mas Wisnu untuk mengadakan perjanjian ritual. Aku diminta untuk menyediakan sejumlah sesajian lengkap untuk menggelar ritual itu. Aku harus menyediakan kembang setaman lengkap dengan kemenyan dan uborampe lainnya.

Singkat cerita ritual tersebut digelar di sebuah tempat keramat di Bogor, Jawa Barat perbatasan Jasinga, Bogor dengan Tangerang Banten. Hari itu Kamis malam Jumat, berdasarkan perhitungan Mas Wisnu, hari itu adalah hari baik untukku dan keluargaku. Ritual itu sendiri baru akan digelar menjelang tengah malam.

Setelah meminta ijin dengan juru kunci, kami langsung menuju lokasi keramat untuk mengenali situasinya. Ternyata tempat keramat ini memang nampak menyeramkan. Pohon-pohon besar berdiri tegak bagaikan raksasa yang tengah berkacak pinggang. Di bawah pohon-pohon besar itu berdiri sebuah gubuk kecil yang gelap gulita. Hanya ada sebuah lampu minyak yang kadang redup tertiup angin.Aku merasakan banyak getaran ghaib yang menyelimuti tempat keramat tersebut.

Pukul 11 malam, Mas Wisnu mulai memerintahkan anak buahnya untuk mempersiapkan segala sesajian yang kami bawa. Berbagai uborampe digelar dalam cungkup yang luasnya sekitar 10 meter persegi itu. Kembang setaman digelar di atas sehelai kain putih. Perapian mulai dibakar dan sesaat kemudian api mulai menyala membakar arang dalam bokor tembaga. Beberapa batang hio mulai mengepulkan asap yang baunya khas menusuk hidung. Terakhir Mas Wisnumencabut sebuah keris yang bernama Omyang Jimber. Keris itu berdiri tegak di atas sehelai kain putih di depan sesajian. Ritual itu mulai digelar.

Tepat tengah malam, mas Wisnu mulai membacakan mantera dan jampi-jampi yang aku tak mengerti. Beberapa bait mantera dan jampi-jampi dari bahasa Jawa kuno meluncur dari mulutnya.Setelah pembacaan mantera itu selesai, lalu Mas Wisnu memerintahkan seorang asistennya yang masih sangat muda untuk duduk di depan sesajian itu. Sesaat kemudian asistennya yang masih anak muda itu menutupi sebuah kardus dengan kain putih. Kemudian dia 
membacakan beberapa mantera sambil duduk bersila di depan sesajian dan kardus itu. Suasana mulai terasa mencekam manakala anak muda itu usai membacakan manteranya. Bulu kudukku terasa lebih merinding dibandingkan beberapa saat lalu. Aku merasa seperti ada makhluk halus yang tengah memperhatikan gerak-gerikku. Sesekali aku mendengar suara burung hantu dan binatang malam yang membuat suasana semakin mencekam. Aku yakin di situ pasti ada makhluk halus yang tengah memperhatikanku. Aku merasakan itu karena hampir seluruh bulu dalam tubuhku berdiri.

Sedang diliputi rasa takut itu, tiba-tiba blarrrrrrrrr. Kardus yang ditutup kain putih itu seperti meledak menimbulkan suara gaduh. Jantungku seperti mau copot, aku kaget bukan kepalang, hingga posisi dudukku berubah sedikit mundur. "Tenang-tenang.. tidak ada apa-apa. Itu hanya sebuah pertanda bahwa ritual kita direstui ghaib dan kita nyaris berhasil." Ujar Mas Wisnu manakala melihat keadaanku yang sangat ketakutan. Tetap konsentasi dan jangan bertindak yang bukan-bukan," lanjutnya.

"Nah, ritual ini telah selesai. Mari kita lihat apa yang ada di dalam kardus itu," tiba-tiba Mas Wisnu membuka kardus itu sesekali aku melihat raut wajahnya yang was-was. "Al-hamdulillah, ternyata ritual kita berhasil. Silahkan liat apa isi kardus ini," tutur Mas Wisnu dengan senyum penuh kebahagiaan.

Dan betapa terkejutnya aku manakala melihat apa yang yang ada dalam kardus itu. Setelah kuperhatikan, ternyata uang yang selama ini aku damba-dambakan untuk melunasi hutanghutangku.Yah, singkat cerita kami pulang dengan membawa hasil yang kami harapkan. Dengan uang itu aku membayar seluruh hutangku. Anehnya uang itu memang hanya cukup untuk membayar hutang. Hanya tersisa dua juta saja dari sisa-sisa pembayaran hutangku itu. Tapi syukur, aku bisa melunasi hutang-hutangku meski kini aku harus kembali usahaku dari nol.

Studi kasus di atas adalah contoh pendekatan ilmu kalam yang percaya pada keris memiliki "kekuatan ghaib".Adapun ritual yang menimbulkan kemusyrikan, antara lain:

\begin{tabular}{|c|c|}
\hline No. & Ritual Syirik Yogi \\
\hline 1. & $\begin{array}{c}\text { Yogi percaya keris Omyang Jimber bisa menarik uang dari alam ghaib. Uang yang } \\
\text { didapatkannya berasal dari keris (kekuatan ghaib roh halus) bukan dari Allah SWT. }\end{array}$ \\
\hline 2. & $\begin{array}{c}\text { Yogi menyediakan sesajen seperti kembang setaman lengkap dengan kemenyan dan uborampe } \\
\text { lainnya. Seseorang yang menyajikan sesajen dengan maksud menjalin hubungan dengan roh } \\
\text { halus yang diyakini sebagai penjaga tempat tertentu, berarti telah menodai bahkan merusak } \\
\text { tauhid. }\end{array}$ \\
\hline 3. & $\begin{array}{c}\text { Yogi percaya perhitungan prambon Hari Kamis malam Jum'at untuk melakukan ritualnya. } \\
\text { Seseorang yang mempercayai ramalan tertentu termasuk perbuatan syirik dalam Islam. }\end{array}$ \\
\hline 4. & Beberapa mantera dan jampi-jampi dari bahasa Kuno meluncur dari mulur Mas Wisnu. \\
\hline 5. & Percaya ritual tersebut memudahkan mendapatkan kekayan (rizki) secara instan (persugihan). \\
\hline
\end{tabular}

$$
\text { Tabel 1. Analisis Ritual Syirik Yogi }
$$

Faktor penyebab Yogi dapat dengan mudah menjadi musyrik disebabkan adanya kekosongan (mental dan material) dan hawa nafsu. Pertama, "kekosongan pengenalan terhadap Tuhan YME", menyebabkan seseorang mudah melakukan syirik. Adanya alam sekitar tidak cukup baginya untuk dijadikan bukti tentang adanya Tuhan YME. Terlihat Yogi spiritual terhadap Tuhannya rendah, dia begitu saja percaya dengan tipu muslihat temannya.

Kedua, "kekosongan harta". Kekosongan harta bisa mengakibatkan seseorang mudah mengikuti syirik, apalagi Yogi ada yang mempengaruhinya dengan hanya diiming-imingi seorang spiritual (Mas Wisnu), dengan menggelar sebuah ritual untuk mendapatkan sebuah uang dari ghaib. Hal ini seperti disinyalir oleh Nabi Muhammad SAW: "Kemiskinan itu mendekati kekufuran." Dalam hubungan ini, Imam "Ali bin Thalib RA pernah mengatakan: "Jika seandainya kemiskinan itu (berbentuk) manusia, maka pasti telah aku bunuh. ",30

Ketiga, "kekosongan ilmu dan pemahaman agama yang dipeluk", bisa juga Yogi menjadi musyrik, karena dia tidak mantap dalam beragama dan tidak mengerti benar tentang agama yang dipeluknya, sehingga mudah terpengaruh dengan hal-hal yang berbau syirik. 
Keempat, "kekosongan pembinaan", Yogi memerlukan pembinaan yang berkesinambung dan berkelanjutan untuk berkomunikasi dengan Allah SWT, seperti salat maupun membaca AlQur'an.

Kelima, "hawa nafsu", Yogi dilumpuhkan dengan hawa nafsunya untuk cepat melunasi hutangnya. Dia melakukan hal yang instan untuk mendapatkan uang.

Berdasarkan uraian di atas jelas, keris sebagai jimat merupakan perbuatan syirik (dosa besar). Mengenai balasan orang yang melakukan syirik setiap aliran memiliki perspektif masing-masing dan berbeda, misalnya:Menurut aliran Khawarij, orang Islam yang melakukan dosa besar adalah kafir, dan harus di bunuh. Menurut aliran Murji'ah,orang Islam yang melakukan dosa besar tidak dihukumkan kafir. Muslim tersebut tetap mukmin selama ia mengakui dua kalimat syahadat. Menurut aliran qadariyah, orang yang berdosa besar itu bukanlah kafir, dan bukanlah mukmin, tapi fasik dan orang fasik itu masuk neraka secara kekal, dan sebagainya. ${ }^{31}$

\section{Analisis Penulis}

Temuan yang penulis dapat setelah melakukan kajian terhadap pendekatan ilmu kalam dalam studi keislaman adalah pertama, bahwa kelebihan pendekatan ilmu kalam adalah menjaga kemurnian dasar-dasar agama dan memberikan dasar-dasar argumentasi yang kuat dihadapan para penentangnya.

Kedua, memberikan arahan dan petunjuk kepada orang-orang yangmembutuhkan nasihat, khususnya jika Islam bersinggungan dengan teologiagama lain dalam masyarakat yang heterogen.Ketiga,menopang danmenguatkan sistem nilai ajaran Islam yang terdiri atas tiga pilar, yaitu: iman sebagai landasan akidah. Islam sebagai manifestasi syariat, ibadah danmuamalah. Serta Ihsan sebagai aktualisasi akhlak.Keempat,menjadi pijakan bagi ilmu-ilmu syariah. Kelima,menjaga kesucian niat dan keyakinan yang merupakan dasar dalam perbuatan untuk mencapai kebahagiaan dunia akhirat.

Salah satu kekurangan pendekatan ilmu kalam, yaitu kendala paradigma burhani yang sering dihadapi dalam penerapan pendekatan burhani ini adalah sering tidak sinkronnya teks dan realitas. Produk ijtihadnya akan berbeda jika dalam permasalahnnya ada yang diutamakan antara teks atau konteks. Sebagaimana kita ketahui bahwa masyarakat lebih banyak memenangkan tekstualitas daripada kontekstualitas, meskipun yang lebih cenderung kepada kontekspun juga tidak sedikit.

Sejauh ini, sah-sah saja menggunakan ilmu kalam sebagai sebuah pendekatan dalam studi keislaman. Penggunaan pendekatan yang pas dengan permasalahan penelitian, menghasilkan penelitian yang baik dan jawaban yang solutif. Meskipun ketika digunakan untuk membaca wajah Islam, pemilihan situasi (kasusuistik) yang tepat, dengan pendekatan ilmu kalam, Islam akan tampil lebih rasional tanpa melanggar al-Qur'an atau pun hadis.

Keris sebagai jimat dengan pendekatan ilmu kalam ini dapat menambah khasanah ilmu, terutama hukum percaya "keris sebagai jimat" haram/dosa besar/musyrik apabila mempercayainya

\section{Kesimpulan}

Dari uraian di atas dapat disimpulkan bahwa pendekatan ilmu kalam adalah cara pandang atau analisis terhadap masalah ketuhanan dengan menggunakan norma-norma agama atau simbolsimbol keagamaan yang ada. Pendekatan ilmu kalam tidak bisa dilepas dari kehidupan umat beragama di tengah-tengah masyarakat.

Masalah keyakinan (akidah) ataupun monoteisme murni (ilmu kalam) merupakan salah satu masalah yang fundamental dalam Islam yang menjadi pijakan umat Islam

\footnotetext{
${ }^{31}$ Fakih, Abdul Latif. 2011. Tauhid (Sebuah Akidah Pembebasan). Pamulang: Inbox., hal 61
} 
dalam kehidupan sehari-hari. Tanpa akidah yang mantap tidak mungkin (mustahil) seseorang bisa mengamalkan ajaran Islam secara sempurna. Adapun beberapa istilah kunci dalam ilmu kalam seperti iman, kufur, nifaq, syirik, dan murtad.

Dahulu keris sengaja dibuat oleh seorang empu untuk senjata perang atau senjata penusuk jarak dekat, yang efektif dalam pertarungan jarak dekat dalam pertarungan satu lawan satu, baik berhadapan muka atau sembunyi-sembunyi. Keris dalam perkembangannya telah mengalami perubahan fungsi, kedudukan keris saat ini bukan lagi sebagai senjata, melainkan sebagai benda peninggalan sejarah, karya seni, koleksi, pusaka, hiasan, dan pelengkap pakaian adat, bahkan keris digunakan sebagai azimat (jimat), yang mana hukumnya haram/dosa besar. Al-Qur'an sudahmenjelaskan bahwa umat muslim diperbolehkanmembuat senjata untuk melindungi diri. Keris adalah salah satu senjatayang berfungsi sebagai pelindung diri dari ancama-ancaman, jadi umatmuslim diperbolehkan memiliki keris jika difungsikan sebagai alatuntuk mempertahankan diri bukan azimat (jimat)

\section{DAFTAR PUSTAKA}

APP. 2007. Al-Qur'an dan Terjemahannya. Jakarta: PT. Indah Kiat Pulp \& Paper Tbk.

Departemen Agama RI. 2010. Al-Hidayah Al-Qur'an Tafsir Perkata Tajwid Kode Angka. Jakarta: Kalim.

Fakih, Abdul Latif. 2011. Tauhid (Sebuah Akidah Pembebasan). Pamulang: Inbox.

Harsrinuksmo, Bambang. 1985. Tanya Jawab Soal Keris. Jakarta: PT. Grafikatama Jaya.

Jamrah, Suryan A. 2015. Studi Ilmu Kalam. Jakarta: Kencana.

Khunaifi, Agus. 2012. Ilmu Tauhid (Sebuah Pengantar Menuju Muslim Moderan). Semarang: CV. Karya Abadi Jaya.

Kristeva, Nur Sayyid Santoso. 2014. Sejarah Teologi Islam dan Akar Pemikiran Ahlussunah Wal Jama'ah. Yogyakarta: Pustaka Pelajar.

Muhammad, Imam Abu Abdullah. 1990. Dosa-Dosa Besar. Surabaya: Bina Ilmu Offset.

Nasir, Salihun A. 2010. Pemikiran Kalam (Teologi Islam) Sejarah, Ajaran, dan Perkembangannya. Jakarta: Rajawali Pers.

Ajahari. 2011. "Memahami Islam Perspektif Metodologis.” Jurnal Tarbiyatuna PAI, Vol. 1 (1)

Dzajimah, Nurul. 2012. "Pendekatan Sosio-Historis Alternatif dalam Memahami Perkembangan Ilmu Kalam.” Jurnal, Vol 11 (1).

Munir, Muhammad Khafidlil. 2015. "Memahami Konsep Keris Menurut Mt Arifin Dalam Tinjauan Islam.” Skripsi S1.

Mustafa, Muhdagin Dg. 2006. "Reorientasi Teologi Islam Dalam Konteks Pluralisme Beragama (Telaah Kritis dengan Pendekatan Teologis Normatif, Dialogis dan Konvergensif).” Jurnal Hunafa, Vol. 3 (2).

Bilikmisteri, Kisah Misteri: Ritual Persugihan Omyang Jimbe, dalam http://www. Bilikmisteri.web.id/, pada 16 November 2016.

Kusein, Rajin Salat Tetapi Percaya Azimat, dalam http: // inilahrisalahislam. blogspot. co. Id / 2016/ 02/rajin-sholat-tapi-percaya-azimat.html, pada 10 Februari 2016. 
Muntaha, Hasan, Pengertian Ilmu Kalam: Fungsi dan Ruang Lingkupnya, dalam http://artikelaz.com/ilmu-kalam/, pada 15 Oktober 2015.

Nalion, Amfa, Pendekatan Teologi Ilmu Kalam, dalam http : // amvanalion. blogspot. co. Id / p /pendekatan-teologiilmu-kalam.html, pada 5 Maret 2015 